studies in developing countries is notable. Barriers include complex ethical challenges, such as those revealed by the randomized HIV-1 perinatal transmission trials in developing countries in the early 1990s, ${ }^{9}$ skepticism of Western regulatory agencies of drugs and devices tested outside of high-income countries and limited research capacity in developing countries. But these barriers are not insurmountable. Making any serious improvement in mortality and disability among the global poor will require much more research, some of it employing randomized designs, into the few major diseases that explain much of the gap between rich and poor countries. Priorities include accelerating declines in childhood and maternal mortality, getting adult smokers worldwide to quit ${ }^{1}$ and, most notably, curbing the growth of HIV $-1 .{ }^{10}$

This article has been peer reviewed.

From the Centre for Global Health Research (Jha, Lavery) and the Centre for Inner City Health Research (Lavery), St. Michael's Hospital, University of Toronto, and the Department of Public Health Sciences (Jha, Lavery) and the Joint Centre for Bioethics (Lavery), University of Toronto, Toronto, Ont.

Competing interests: None declared.

Contributors: Both authors drafted and revised the article and approved the final version.

\section{References}

1. Jha P, Mills A, Hanson K, Kumaranayake L, Conteh L, Kurowski C, et al. Improving the health of the global poor. Science 2002;295:2036-9.

2. Black RE, Morris SS, Bryce J. Where and why are 10 million children dying every year? Lancet 2003;361(9376):2226-34

3. Easterlin RA. How beneficent is the market? A look at the modern history of mortality. Eur Rev Econ Hist 1999;3(3):257-94.

4. World Health Organization. Investing in bealth research and development: report of the Ad Hoc Committee on Health Research Relating to Future Intervention Options. Geneva: The Organization; 1996. Rep no TDR/Gen/96.1.

5. Rochon PA, Mashari A, Cohen A, Misra A, Laxer D, Streiner DL, et al. Relation between randomized controlled trials published in leading general medical journals and the global burden of disease. CMA7 2004;170(11):1673-7.

6. Committe on the NIH Research Priority-Setting Process, Institute of Medicine. Scientific opportunities and public needs: improving priority setting and public input at the National Institutes of Health. Washington: The Institute; 1998

7. Gwatkin DR, Heuveline P. Improving the health of the world's poor. BMf 1997;315(7107):497-8.

8. World Health Organization. World bealth report 2002: making a difference Geneva: The Organization; 2002

9. London AJ. Equipoise and international human subjects research. Bioethics $Q$ 2001;15(4):312-32

10. Jha P, Nagelkerke JD, Ngugi EN, Prasada Rao JV, Willbond B, Moses S, et al. Reducing HIV transmission in developing countries. Science 2001;292 (5515):224-5.

Correspondence to: Dr. Prabhat Jha, Director, Centre for Global Health Research, St. Michael's Hospital, University of Toronto, 70 Richmond St. E, Third floor, Toronto ON M5C 1N8; fax 416 864-5256; prabhat.jha@utoronto.ca

\title{
Health care as a risk factor
}

\section{Peter Davis}

ß See related article page 1678

$\mathrm{T}$ he article by Baker and associates in this issue (see page 1678) adds to the growing body of evidence that health care, though undoubtedly beneficial, also has potentially harmful effects on patients. ${ }^{1}$ According to the estimates published here, nearly 70000 annual hospital admissions in Canada are associated with an adverse event (AE) that was preventable. Most are relatively minor, but a good proportion (20.8\%) result in death. The impact on an already overtaxed system is not to be underestimated: patients experiencing AEs require a longer stay in hospital and may need more intensive care. What are we to make of these results? Are they sound? If so, what can be done about them? Or, are they a risk that we must accept in a world of increasingly complex and powerful therapeutic interventions with patients who are ever more frail?

Baker and associates followed a swath of investigations with similar methodologies published in the United States, Australia, the United Kingdom, Denmark and New Zealand. ${ }^{2-10}$ This is one of the study's strengths. Science establishes fact by replicating results under different conditions. Indeed, in some respects, this investigation pushes the boundaries in the field. It is probably the first study of AEs that can safely claim to be nationally representative, since the investigators selected hospitals of different sizes from 5 of Canada's most populous provinces. Furthermore, electronic data collection instruments may well have improved accuracy.

In scientific terms, the study results are reassuringly robust and familiar. There are some variations, of course. The overall $\mathrm{AE}$ rate ( $7.5 \%$ of all hospital admissions) is closer to European than to American findings. The proportion of AEs associated with death seems high when compared with that of other studies, and the proportion of AEs attributable to system-related events (just over $3.0 \%$ ) is lower. But in other respects, including the distinctive distribution of AEs across hospital services (higher in surgery) and patient ages (higher among elderly patients), as well as a variety of other factors, the results are comparable with those of other studies.

One conclusion we can draw from this study is that, although the populations of Western societies might enjoy all the benefits of affluence and modern medical care, they 
also run a significant risk as patients. The hazard of AEs is contextual in nature and seems to be relatively uniform regardless of medicolegal culture, sociocultural setting and type of health care system. In New Zealand we have quantified what is in effect a newly discovered public health risk. Of the top 20 risk factors that account for nearly threequarters of all deaths annually, adverse in-hospital health care events come in at number 11, above air pollution, alcohol and drugs, violence and road traffic injury, among others. ${ }^{11}$ Indeed, at 1500 deaths annually, this equals a third of the 5000 deaths attributed to tobacco each year.

The painful paradox is that, by lavishing ever more care on our patients, we may also be exposing them to a potential hazard.This is underlined by Baker and associates' finding that the $\mathrm{AE}$ rate was higher in teaching hospitals. Are these really more dangerous places than humbler institutions? The fact that the preventable $\mathrm{AE}$ rate was no higher in teaching hospitals suggests that quality was not the crucial factor. Rather, it may be that in a hospital-oriented referral system, the unchallenged therapeutic imperative of modern medicine to move patients to a higher level of intervention than they can — or even should — sustain needs to be re-examined. Other options may exist, particularly for older patients, who bear a disproportionate share of the iatrogenic burden.

At one level, treatment injury is a public health issue. It is a significant risk factor, associated with demonstrable variables, and there are clear opportunities for prevention. Although the results of this study do not bring this out, infection is likely an important source of harm, and it is one for which there are well-established control strategies. Other major areas where established procedures can be enhanced are the prescription and administration of medications. Indeed, a combination of evidence-based practice supported by information technology would go a long way to reducing the $\mathrm{AE}$ rate. Within the complexity of the modern hospital environment, we need to address issues of coordination, competence and communication. Stable team structures, openness to cross-professional exchange and sturdy peer-review mechanisms are vital factors in work organization, the lack of which contribute to the potential for AEs.

At another level, treatment injury is also a matter of human rights. Patients need to be made more aware of the level of risk involved in a particular course of treatment. When things go wrong, they must be informed. Their concerns - yes, even their complaints - must guide the system. And, if injured, they deserve rehabilitation, explanation and even compensation. Just as employees harmed at work might expect redress for the unwanted and possibly unanticipated risk to which they have been exposed, so patients harmed at a hospital - and their caregivers - might welcome an environment in which their claims can be heard. In New Zealand, for example, treatment injury is dealt with as a special case of accidental harm. Patients and their relatives do not have to litigate to receive compensa- tion for AEs that result in injury or permanent harm or death. Instead, they approach the Accident Compensation Corporation, which administers a tax-based fund. ${ }^{12}$ Furthermore, in order to secure accountability for harm whether it be an apology, remedial training or discipline patients do not have to risk the courts either; they work through a semi-judicial complaints system headed by a health and disability commissioner. ${ }^{13}$

As with any matter of public policy, responding to AEs requires a mixture of sound empirical evidence, balanced scientific assessment and solid ethical grounding. The great contribution of studies such as Baker and associates' is that, for the first time, we have indisputable facts of a representative character. Those facts must be assessed against a balanced set of scientific criteria. What interventions are costeffective? Which are most easily implemented and likely to have the greatest effect? Finally, we need an ethical debate on the purpose of medicine, placing the requirements of the patient at its core.

Peter Davis is Professor of Public Health, Christchurch School of Medicine and Health Sciences, University of Otago, New Zealand.

Competing interests: None declared.

\section{References}

1. Baker GR, Norton PG, Flintoft V, Blais R, Brown A, Cox J, et al. The Canadian Adverse Events Study: the incidence of adverse events among hospital patients in Canada. CMA7 2004;170(11):1678-86.

2. Brennan TA, Leape LL, Laird NM, Hebert L, Localio AR, Lawthers AG, et al. Incidence of adverse events and negligence in hospitalized patients. Results of the Harvard Medical Practice Study I. N Engl 7 Med 1991;324(6):370-7.

3. Wilson RM, Runciman WB, Gibberd RW, Harrison BT, Newby L, Hamilton JD. The Quality in Australian Health Care Study. Med 7 Aust 1995;163 (9):458-76.

4. Leape LL, Brennan TA, Laird N, Lawthers AG, Localio AR, Barnes BA, et al. The nature of adverse events in hospitalized patients. Results of the Harvard Medical Practice Study II. N Engl F Med 1991;324(6):377-84.

5. Thomas EJ, Studdert DM, Burstin HR, Orav EJ, Zeena T, Williams EJ, et al. Incidence and types of adverse events and negligent care in Utah and Colorado. Med Care 2000;38(3):261-71.

6. Davis P, Lay-Yee R, Briant R, Schug S, Scott A, Johnson S, et al. Adverse events in New Zealand public hospitals: principal findings from a national survey. Wellington: NZ Ministry of Health; 2001. Available: www.moh.govt.nz/publications /adverseevents (accessed 2004 Apr 28).

7. Vincent C, Neale G, Woloshynowych M. Adverse events in British hospitals: preliminary retrospective record review [published erratum in $B M \mathcal{F}$ 2001;322:1395]. BM7 2001;322(7285):517-9.

8. Davis P, Lay-Yee R, Briant R, Ali W, Scott A, Schug S. Adverse events in New Zealand public hospitals I: occurrence and impact. $N$ Z Med 7 2002;115(1167):U271.

9. Davis P, Lay-Yee R, Briant R, Ali W, Scott A, Schug S. Adverse events in New Zealand public hospitals II: preventability and clinical context. $N Z \mathrm{Med}$ 7 2003;116(1183):U624.

10. Schioler T, Lipczak H, Pedersen BL, Mogensen TS, Bech KB, Stockmarr A, et al. Danish Adverse Event Study [Incidence of adverse events in hospitals. A retrospective study of medical records]. Ugeskr Laeger 2001;163(39):5370-8.

11. Looking upstream: causes of death cross-classified by risk and condition, New Zealand 1997. Public Health Intelligence Occasional Bulletin no 20. Wellington: NZ Ministry of Health; 2004.

12. Dyson R. Review of ACC medical misadventure. Consultation document. Wellington: NZ ACC and Department of Labour; 2003.

13. Paterson R. The patients' complaints system in New Zealand. Health Affairs 2002;21(3):70-9.

Correspondence to: Dr. Peter Davis, Professor of Public Health, University of Otago, PO Box 4345, Christchurch, New Zealand 